\title{
Global epidemiology of podoconiosis: A systematic review
}

\author{
Kebede Deribe $^{1,2 *}$, Jorge Cano ${ }^{3}$, Mei L. Trueba ${ }^{1}$, Melanie J. Newport ${ }^{1}$, Gail Davey ${ }^{1}$ \\ 1 Wellcome Trust Brighton and Sussex Centre for Global Health Research, Brighton and Sussex Medical \\ School, Brighton, United Kingdom, 2 School of Public Health, Addis Ababa University, Addis Ababa, Ethiopia, \\ 3 Department of Disease Control, London School of Hygiene \& Tropical Medicine, London, United Kingdom \\ *kebededeka@yahoo.com
}

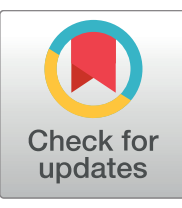

\section{G openaccess}

Citation: Deribe K, Cano J, Trueba ML, Newport MJ, Davey G (2018) Global epidemiology of podoconiosis: A systematic review. PLoS Negl Trop Dis 12(3): e0006324. https://doi.org/10.1371/ journal.pntd.0006324

Editor: Pamela L. C. Small, University of Tennessee, UNITED STATES

Received: January 20, 2018

Accepted: February 16, 2018

Published: March 1, 2018

Copyright: @ 2018 Deribe et al. This is an open access article distributed under the terms of the Creative Commons Attribution License, which permits unrestricted use, distribution, and reproduction in any medium, provided the original author and source are credited.

Data Availability Statement: All relevant data are within the paper and its Supporting Information files.

Funding: $K D$ is supported by a grant from the Wellcome Trust [grant number 201900] as part of his Intermediate Fellowship in Public Health and Tropical Medicine. The funders had no role in study design, data collection and analysis, decision to publish, or preparation of the manuscript.

Competing interests: The authors have declared that no competing interests exist.

\section{Abstract}

\section{Background}

Podoconiosis is one of the few diseases that could potentially be eliminated within one generation. Nonetheless, the global distribution of the disease remains largely unknown. The global atlas of podoconiosis was conceived to define the epidemiology and distribution of podoconiosis through dedicated surveys and assembling the available epidemiological data.

\section{Methods}

We have synthesized the published literature on the epidemiology of podoconiosis. Through systematic searches in SCOPUS and MEDLINE from inception to February 14, 2018, we identified observational and population-based studies reporting podoconiosis. To establish existence of podoconiosis, we used case reports and presence data. For a study to be included in the prevalence synthesis, it needed to be a population-based survey that involved all residents within a specific area. Studies that did not report original data were excluded. We undertook descriptive analyses of the extracted data. This study is registered with PROSPERO, number CRD42018084959.

\section{Results}

We identified 3,260 records, of which 27 studies met the inclusion criteria. Podoconiosis was described to exist or be endemic in 32 countries, 18 from the African Region, 3 from Asia and 11 from Latin America. Overall, podoconiosis prevalence ranged from $0.10 \%$ to $8.08 \%$, was highest in the African region, and was substantially higher in adults than in children and adolescents. The highest reported prevalence values were in Africa $(8.08 \%$ in Cameroon, $7.45 \%$ in Ethiopia, $4.52 \%$ in Uganda, 3.87\% in Kenya and $2.51 \%$ in Tanzania). In India, a single prevalence of $0.21 \%$ was recorded from Manipur, Mizoram and Rajasthan states. None of the Latin American countries reported prevalence data.

\section{Conclusion}

Our data suggest that podoconiosis is more widespread in the African Region than in the rest of the regions, although this could be related to the fact that most podoconiosis 
epidemiological research has been focused in the African continent. The assembled dataset confirms that comprehensive podoconiosis control strategies such as promotion of footwear and personal hygiene are urgently needed in endemic parts of Africa. Mapping, active surveillance and a systematic approach to the monitoring of disease burden must accompany the implementation of podoconiosis control activities.

\section{Author summary}

Podoconiosis is one of the Neglected Tropical Diseases, and causes painful and massive swelling of the lower legs. Despite the importance of the disease, its global distribution and epidemiology are poorly understood. We conducted a systematic review to assess the global epidemiology of podoconiosis. We found that podoconiosis was described to exist or be endemic in 32 countries, 18 from Africa, 3 from Asia and 11 from Latin America. Almost all prevalence data recorded corresponded to the African region. None of the Latin American countries reported prevalence data, although some countries are suspected to be endemic. We recommend that comprehensive podoconiosis control strategies such as promotion of footwear and personal hygiene are urgently needed in endemic countries in the African Region. Mapping, active surveillance and a systematic approach to the monitoring of disease burden must accompany the implementation of podoconiosis control activities.

\section{Introduction}

Podoconiosis is a neglected tropical disease caused by exposure to red clay soil $[1,2]$. The disease results from a complex interaction between genes and the environment occurring over many years. Mineral particles from the soil penetrate the skin and are taken up by macrophages in the lymphatic system which causes inflammation and fibrosis of the vessel lumen leading to blockage of the lymphatic drainage. This results in oedematous feet and legs and subsequently progresses to elephantiasis, including nodular skin changes [3]. These changes are themselves disabling, and painful intermittent acute inflammatory episodes cause further debility[4].

Current global estimates suggest that there are 4 million cases of podoconiosis in Africa, parts of Latin America and South East Asia[5, 6]. In 2011, the World Health Organization (WHO) included podoconiosis in the list of neglected tropical diseases (NTDs)[7]. Intervention includes prevention through consistent use of footwear starting from an early age, regular foot hygiene and covering housing floors. For those with the disease, simple lymphedema management consisting of foot hygiene, foot care, wound care, compression, exercises and elevation, treatment of acute attacks and use of shoes and socks to reduce further exposure to the irritant soil is recommended [8].

Despite increased global interest in podoconiosis, the global epidemiology of the disease is largely uncertain [9]. This is partly due to the absence of accurate and easy-to-use diagnostic tools such as a point-of-care diagnostic test. Currently, diagnosis is clinical and based on exclusion of other potential causes of lymphedema in the tropics, mostly lymphatic filariasis but also certain forms of leprosy, Milroy syndrome and heart or liver failure, for example. [10]. Nonetheless, in endemic areas trained health workers can easily identify the disease [11]. 
Although high prevalence of podoconiosis has been reported intermittently across a range of settings, it has never been prioritized either in intervention or research programmes. This may be due to the lack of resources for new health initiatives, which is a common problem in the low-income tropical countries in which this disease is present. Only two countries (Ethiopia and Rwanda) report podoconiosis within their routine health management information systems [12]. In other well-known or suspected endemic countries, the existence of podoconiosis is based on cross-sectional surveys, case reports and presence reports intended to ascertain the disease presence and burden in specific areas [13, 14].Therefore, to understand the global distribution of podoconiosis, compiling the existing evidence is of utmost importance. Keeping these repositories of epidemiological data up-to-date will be relevant for further monitoring and evaluation of interventions put in place, as similar experiences have come to demonstrate [15, 16]. Price's monograph published in 1990 [3] is the first attempt to review the distribution of podoconiosis globally. Despite being a comprehensive work, it did not follow current systematic guidelines on data assembling and survey selection.

Building upon this first experience, we have conducted a systematic review of studies reporting prevalence data of podoconiosis across major libraries of scientific literature and through searches on gray literature (i.e. unpublished reports, monographies, etc.). In addition, we undertook a descriptive analysis of the extracted data.

\section{Materials and methods}

\section{Search strategy and selection criteria}

We searched for studies that reported the epidemiology of podoconiosis, using a systematic review approach that followed the Preferred Reporting Items for Systematic Reviews and Meta-Analyses (PRISMA) [17] (Fig 1). We searched MEDLINE from inception (coverage from 1950) to 14 February 2018 and SCOPUS (from 1966 to 14 February, 2018) for all relevant studies that examined podoconiosis prevalence. We used the following search terms; 'podoconiosis' OR 'mossy foot' OR 'non-filarial elephantiasis' combined with 'prevalence', 'epidemiol-

ogy', 'public health', 'population' (see S1 Text: Supplementary File). No time, geographical area or language limits were applied. We hand-searched the reference lists of all recovered documents for additional references. Abstracts of all reports were read, and full papers retrieved for those appearing to fulfill selection criteria, as it is detailed below (Fig 1). This analysis is reported using recommended criteria (see S1 Checklist).

We searched the gray literature by seeking reports not published in peer reviewed journals through contacting experts, a search of conference abstracts and reviewing Price's monograph [12].

\section{Study selection}

We screened search results first by title and abstract and then by full text. We disregarded abstracts in the initial screen if they were not observational studies and did not investigate the epidemiology of podoconiosis. We also excluded studies that did not report original data (e.g. review articles). Abstracts reporting observational studies and/or focusing on podoconiosis were eligible for full-text review. Population-based articles were independently considered for inclusion in the review if the studies reported prevalence of podoconiosis or contained adequate information to calculate prevalence. By 'population-based' articles we meant studies which involved all residents within a specific area and in which the studied population was representative of that area. We excluded studies based on data recorded in health facilities. When the same data were reported in two or more publications, we selected the most comprehensive source. Lastly, we identified papers outside the search strategy using expert knowledge 


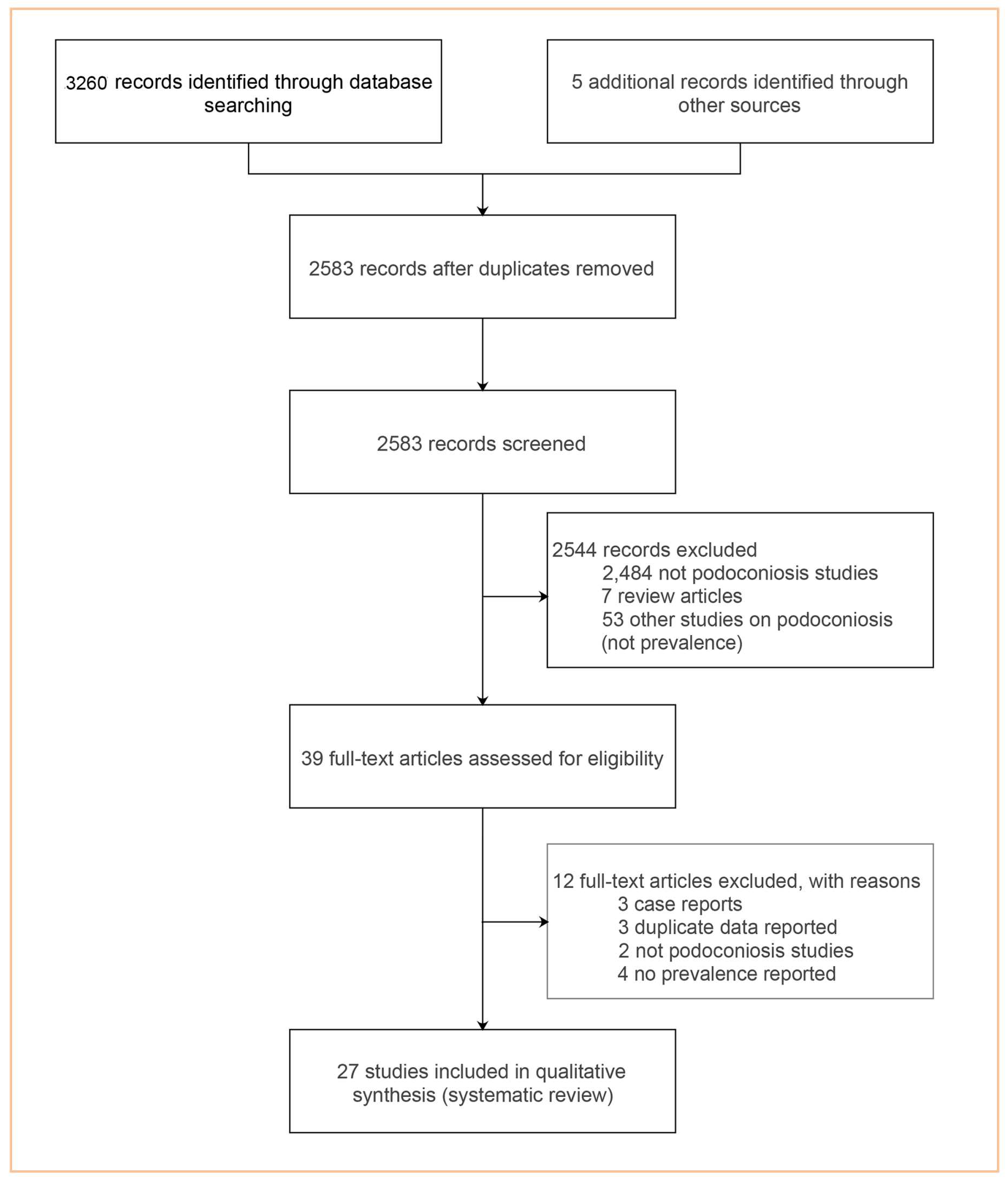

Fig 1. Selection of eligible studies. 
of active studies and contacting experts. When possible, we contacted authors to provide data not presented in their reports.

\section{Study eligibility and quality assessment}

All studies reporting the prevalence of podoconiosis at community level were included. Case reports and presence data were used to identify countries which are currently endemic or those previously endemic. All titles and abstracts of the identified studies were assessed for relevance for the review by two authors using a third author to resolve any discordance. Relevant full text articles were retrieved and checked by two authors (KD and JC) independent of each other, with reference to GD in case of differences. Non-English language papers were translated using Google Translate (Google, Mountain View, CA, USA) or by colleagues proficient in the language in question.

The quality of the studies was assessed by two authors, with disagreement resolved by referral to a third author. The quality of the studies in the review was assessed against four criteria: definition of sampling frame, response rate, quality of podoconiosis assessment and reporting bias (S1 Text. Supplementary File). We adopted the quality assessment framework set by the Newcastle-Ottawa Scale [18]. The four criteria were assessed on a three-point numerical scale $(0,1$, or 2$)$ and involved evaluation of the sampling frame, attrition rate (through assessment of non-response), the measurement criteria (through evaluation of podoconiosis diagnosis criteria), and assessment of reporting bias (by showing how well the study covered reporting of age and other key population descriptions).

\section{Data extraction and synthesis}

After searching for the data in MEDLINE all the references were exported to EndNote X7 (endnote.com).A standardized Microsoft Excel data extraction form was developed and used to record the following information for all qualifying studies: study ID, author, title, journal, the year of study, study design, geographical location (area and country), sample size, number of cases, descriptive case data (e.g., age, sex) and diagnostic method.

We collected data on prevalence with $95 \%$ confidence intervals (CIs). Data were extracted by two authors (KD, JC) with any disagreements referred to a third author (GD) for resolution. We then exported the data to STATA statistical suite (Version 15.0, StataCorp LP, College Station, Texas, USA) for further analysis.

We undertook descriptive analyses of the extracted data. Prevalence estimates are presented with $95 \%$ CIs for those studies with reported cases of podoconiosis and a reported sample size. All analyses were conducted within the STATA statistical suite.

We downloaded the base map of the global administrative areas from the GADM (www. gadm.org) [19]. Point maps displaying the distribution of data points and average podoconiosis prevalence were produced using ArcGIS Desktop v10.3 (Environmental Systems Research Institute Inc., Redlands CA, USA).

This systematic review is registered in the PROSPERO International Prospective Register of systematic reviews, registration number CRD42018084959 (https://www.crd.york.ac.uk/ prospero/display_record.php?RecordID=84959).

\section{Results}

Our systematic review identified 3,260 records through the database search and 5 additional records through the manual search for gray literature. After duplicates were removed, 2,583 studies were screened based on their titles and abstracts. Thirty-nine articles were assessed for eligibility. As a result of this assessment, 27 studies met the inclusion criteria and were included 
in the systematic review $[3,4,14,20-49]$, see Fig 1 . The list of included studies is provided in Table 1.

Overall, the quality of the studies included in the review was poor (S1 Text: Supplementary File). The commonest issue with study quality was the lack of detail on the diagnosis of podoconiosis. Only three studies met the quality standard in all four criteria, 18 studies described the sampling frame thoroughly, 7 studies provided the response rate, and 16 studies satisfactorily included a report on podoconiosis assessment. The scale of the surveys differed, some focused on an entire province, whereas others focused on randomly selected communities or households. The largest studies were conducted in Africa: in Ethiopia two studies included 247,908 [40] and 129,959 individuals [29], in Rwanda over 20,446 [42], and in Cameroon 10,178 [50]. In this region, the smallest sample size reported in a study was 301 participants in Cameroon [22].

To document the countries with current and historical presence of the disease, we compiled case and presence reports. Overall, 32 countries reported existence of podoconiosis now or previously. For eleven of them, prevalence data were available (Burundi [42], Cameroon, Cape Verde, Equatorial Guinea, Ethiopia, India, Kenya, Rwanda [42], Sao Tome \& Principe, Uganda and Tanzania), two countries had case data (Brazil [ 1 case] and Sudan [28 cases]) [3] and 19 countries reported presence without case data (Angola, Chad, Colombia, Costa Rica, Democratic Republic of Congo, Ecuador, El Salvador, French Guiana, Guatemala, Honduras, Indonesia, Madagascar, Mexico, Mozambique, Niger, Nigeria, Peru, Sri Lanka, and Suriname) [3]. (Table 2)

Eighteen countries reporting podoconiosis were from Africa, 3 from Asia and 11 from Latin America. All but one of the countries reporting prevalence data were in Africa (10), the exception being India. None of the Latin American countries reported prevalence data, only Brazil reported case data, and the remainder reported observations without specific case data (Fig 2).

The prevalence studies covered 11 countries, ten of them within the African region: Burundi, Cameroon, Cape Verde, Equatorial Guinea, Ethiopia, Kenya, Rwanda, Sao Tome \& Principe, Uganda and Tanzania. The remaining study was from three states in India: Manipur, Mizoram and Rajasthan. The prevalence of podoconiosis was recorded in 27 studies and ranged from $0.1 \%$ in Uganda [53] to $8.08 \%$ in Cameroon [49]. Of the 27 studies reporting prevalence, 13 were conducted in Ethiopia where prevalence ranged from 2.73\% to 7.45\% [4, 20, 21, $29,30,32,33,35,37,38,40,41,48]$. Podoconiosis is widespread in Ethiopia with more than 345 districts endemic for the disease [59]. The national average prevalence is estimated to be 4.0\% [29]. Another study reported 1.6 million people living with podoconiosis in Ethiopia with 35 million people at risk of the disease in the country [59, 60]. Cameroon is the other country where complete mapping of the distribution of podoconiosis has been done. The prevalence of podoconiosis in Cameroon ranges from $0.5 \%$ to $8.08 \%$ [49, 50]. Podoconiosis is widespread in Cameroon and found in every region of the country.

High prevalence of podoconiosis was also recorded in other countries, including $4.52 \%$ in Uganda [39], 3.87\% in Kenya [26, 52], and 0.99\% in Burundi [42]. In Rwanda, the prevalence of podoconiosis is estimated at $0.63 \%$ [42], whereas in Sao Tome \& Principe it is $0.92 \%$ [45] (Fig 3).

Overall, 6 studies reported prevalence by age group $[4,29,32,39,49,50]$. The prevalence of podoconiosis was higher among adults than children $[4,32,39]$. Of the three studies including children under 10 years old, two reported $0 \%$ prevalence $[4,39]$ whilst one reported 0.4\%[32]. In Ethiopia and Cameroon, the prevalence of podoconiosis increased with age (Fig 4). 
Table 1. Podoconiosis prevalence studies included in the review.

\begin{tabular}{|c|c|c|c|c|c|c|c|}
\hline $\begin{array}{l}\text { Study, study or } \\
\text { publication year }\end{array}$ & $\begin{array}{l}\text { Year of } \\
\text { study }\end{array}$ & Country & Location & Sampling method & Case ascertainment & $\begin{array}{l}\text { Case (sample } \\
\text { size) }\end{array}$ & $\begin{array}{l}\text { Prevalence, \% } \\
(95 \% \mathrm{CI})\end{array}$ \\
\hline \multicolumn{8}{|l|}{ Africa } \\
\hline Price, 1976[42] & 1976 & $\begin{array}{l}\text { Burundi \& } \\
\text { Rwanda }\end{array}$ & Nationwide & Market survey & $\begin{array}{l}\text { Observation of frank } \\
\text { lymphoedema }\end{array}$ & $\begin{array}{l}\text { Burundi } 61 \\
(6,156) \\
\text { Rwanda } 128 \\
(20,446)\end{array}$ & $\begin{array}{c}0.99(0.77-1.27) \\
0.63(0.53-0.75)\end{array}$ \\
\hline Wanji et al 2008[49] & 2006 & Cameroon & $\begin{array}{l}\text { North West province, Ndop } \\
\text { and Tubah }\end{array}$ & $\begin{array}{l}\text { Community } \\
\text { based }\end{array}$ & $\begin{array}{l}\text { Clinical, parasitological } \\
\text { and entomological }\end{array}$ & $66(817)$ & $8.08(6.21-9.95)$ \\
\hline $\begin{array}{l}\text { Cho-Ngwa et al., } \\
2009[22]\end{array}$ & 2003 & Cameroon & $\begin{array}{l}\text { Bambui Health District of } \\
\text { NW Cameroon }\end{array}$ & $\begin{array}{l}\text { Community } \\
\text { based }\end{array}$ & $\begin{array}{l}\text { Clinical and } \\
\text { parasitological }\end{array}$ & $16(301)$ & $5.32(3.30-8.46)$ \\
\hline Wanji et al.,2016[13] & 2016 & Cameroon & $\begin{array}{l}\text { Bafut, Bamenda, Batibo, } \\
\text { Mbengwi, Ndop and Tubah }\end{array}$ & $\begin{array}{l}\text { Community } \\
\text { based }\end{array}$ & Clinical & $1069(56,479)$ & $1.90(1.80-2.00)$ \\
\hline $\begin{array}{l}\text { Deribe et al.,2017 } \\
\text { [50] }\end{array}$ & 2017 & Cameroon & Nationwide & $\begin{array}{l}\text { Community } \\
\text { based }\end{array}$ & $\begin{array}{l}\text { Clinical, parasitological, } \\
\text { and molecular }\end{array}$ & $52(10,178)$ & $0.50(0.40-0.70)$ \\
\hline Price 1990[3] & 1988 & $\begin{array}{l}\text { Equatorial } \\
\text { Guinea }\end{array}$ & $\begin{array}{l}\text { Bioko Island } \\
\text { Equatorial Guinea }\end{array}$ & $\begin{array}{l}\text { Community } \\
\text { based }\end{array}$ & Clinical & $26(3577)$ & $0.73(0.50-1.07)$ \\
\hline Bekele et al.,2016[4] & 2015 & Ethiopia & Wayu Tuka woreda & $\begin{array}{l}\text { Community } \\
\text { based }\end{array}$ & Clinical & $1,197(39,256)$ & $3.05(2.90-3.20)$ \\
\hline $\begin{array}{l}\text { Deribe et al, } 2015 \\
\text { [29] }\end{array}$ & 2013 & Ethiopia & Nationwide & $\begin{array}{l}\text { Community } \\
\text { based }\end{array}$ & Clinical and ICT & $\begin{array}{l}5,253 \\
(129,959)\end{array}$ & $4.04(3.93-4.15)$ \\
\hline $\begin{array}{l}\text { Tekola Ayele et al, } \\
\text { 2013[48] }\end{array}$ & 2011 & Ethiopia & Bedele Zuria district & $\begin{array}{l}\text { Community } \\
\text { based }\end{array}$ & Clinical & $379(6,710)$ & $5.65(5.12-6.23)$ \\
\hline Molla et al, 2012[38] & 2011 & Ethiopia & $\begin{array}{l}\text { Debre Eliyas and Dembecha } \\
\text { districts }\end{array}$ & $\begin{array}{l}\text { Community } \\
\text { based }\end{array}$ & Clinical & $1,704(51,017)$ & $3.34(3.19-3.50)$ \\
\hline $\begin{array}{l}\text { Geshere Oli et al, } \\
2012[33]\end{array}$ & 2012 & Ethiopia & Midakegn district & $\begin{array}{l}\text { Community } \\
\text { based }\end{array}$ & Clinical, parasitological & $123(1,656)$ & $7.43(6.26-8.79)$ \\
\hline Alemu et al, 2011[20] & 2011 & Ethiopia & Gulliso woreda & $\begin{array}{l}\text { Community } \\
\text { based }\end{array}$ & Clinical & $1,935(69,465)$ & $2.79(2.67-2.92)$ \\
\hline Desta et al, 2007[30] & 2001 & Ethiopia & Wolaitta Zone & $\begin{array}{l}\text { Community } \\
\text { based }\end{array}$ & Clinical & $1890(33,678)$ & $5.46(5.21-5.71)$ \\
\hline $\begin{array}{l}\text { Birrie et al., } 1997 \\
\text { [21] }\end{array}$ & 1997 & Ethiopia & Pawe settlement area & $\begin{array}{l}\text { Community } \\
\text { based }\end{array}$ & Clinical, parasitological & $68(1,900)$ & $3.58(2.83-4.51)$ \\
\hline $\begin{array}{l}\text { Frommel et al, } 1993 \\
\text { [32] }\end{array}$ & 1993 & Ethiopia & Ocholo & $\begin{array}{l}\text { Community } \\
\text { based }\end{array}$ & Clinical & $153(3,022)$ & $5.06(4.33-5.90)$ \\
\hline $\begin{array}{l}\text { Kloos et al., } 1992 \\
\text { [35] }\end{array}$ & 1992 & Ethiopia & $\begin{array}{l}\text { Gera \& Didessa, } \\
\text { Western Ethiopia }\end{array}$ & $\begin{array}{l}\text { Community } \\
\text { based }\end{array}$ & Clinical & $31(416)$ & $7.45(5.30-10.52)$ \\
\hline $\begin{array}{l}\text { Mengistu et al., } 1987 \\
\text { [37] }\end{array}$ & 1987 & Ethiopia & Ocholo Gamo Gofa & $\begin{array}{l}\text { Community } \\
\text { based }\end{array}$ & Clinical & $146(2,689)$ & $5.43(4.64-6.35)$ \\
\hline Price,1974 [51] & 1974 & Ethiopia & $\begin{array}{l}\text { Wolaitta Zone, Wajifo, } \\
\text { Shenoe and Alaba }\end{array}$ & Market survey & $\begin{array}{l}\text { Observation of frank } \\
\text { lymphoedema }\end{array}$ & $1781(43,573)$ & $4.09(3.91-4.28)$ \\
\hline Oomen, 1969 [40] & 1969 & Ethiopia & Nationwide & Market survey & $\begin{array}{l}\text { Observation of frank } \\
\text { lymphoedema }\end{array}$ & $\begin{array}{l}6770 \\
(247,908) \\
\end{array}$ & $2.73(2.67-2.79)$ \\
\hline Crivelli, 1986 [26] & 1986 & Kenya & Nyambene Range & $\begin{array}{l}\text { Community } \\
\text { based }\end{array}$ & $\begin{array}{l}\text { Clinical and } \\
\text { parasitological }\end{array}$ & $105(2,711)$ & $3.87(3.21-4.66)$ \\
\hline Muli et al, 2017 [52] & 2017 & Kenya & $\begin{array}{l}\text { Mt. Longonot region in } \\
\text { Nakuru County }\end{array}$ & $\begin{array}{l}\text { Community } \\
\text { based }\end{array}$ & $\begin{array}{l}\text { Clinical, parasitological } \\
\text { and molecular }\end{array}$ & $13(385)$ & $3.40(1.80,5.70)$ \\
\hline Ruiz 1994 [45] & 1988 & $\begin{array}{l}\text { Sao Tome \& } \\
\text { Principe }\end{array}$ & $\begin{array}{l}\text { Districts of } \\
\text { Cantagalo and Lemba }\end{array}$ & $\begin{array}{l}\text { Community } \\
\text { based }\end{array}$ & Clinical and pathological & $11(1,200)$ & $0.92(0.52-1.64)$ \\
\hline $\begin{array}{l}\text { Onapa et al., } 2001 \\
\text { [39] }\end{array}$ & 1998 & Uganda & Kapchorwa District & $\begin{array}{l}\text { Community } \\
\text { based }\end{array}$ & $\begin{array}{l}\text { Clinical, parasitological } \\
\text { and entomological }\end{array}$ & $26(575)$ & $4.52(3.10-6.54)$ \\
\hline $\begin{array}{l}\text { Kihembo et al., } 2017 \\
\text { [53] }\end{array}$ & 2015 & Uganda & $\begin{array}{l}\text { Kamwenge District, western } \\
\text { Uganda }\end{array}$ & $\begin{array}{l}\text { Community } \\
\text { based }\end{array}$ & Clinical and ICT & $52(51,553)$ & $0.10(0.10-0.10)$ \\
\hline $\begin{array}{l}\text { De Meira et al, } 1947 \\
\text { [28] }\end{array}$ & 1947 & Cape Verde & Island of S. Nicolau & $\begin{array}{l}\text { Community } \\
\text { based survey }\end{array}$ & $\begin{array}{l}\text { Clinical, parasitological } \\
\text { and histological }\end{array}$ & $21(7,000)$ & $0.30(0.20-0.46)$ \\
\hline
\end{tabular}


Table 1. (Continued)

\begin{tabular}{l|l|l|l|l|l|l|l}
\hline $\begin{array}{l}\text { Study, study or } \\
\text { publication year }\end{array}$ & $\begin{array}{l}\text { Year of } \\
\text { study }\end{array}$ & Country & Location & Sampling method & Case ascertainment & $\begin{array}{l}\text { Case (sample } \\
\text { size) }\end{array}$ & $\begin{array}{l}\text { Prevalence, \% } \\
(\mathbf{9 5 \%} \text { CI) }\end{array}$ \\
\hline $\begin{array}{l}\text { Jordan et al., } 1956 \\
{[34]}\end{array}$ & 1956 & Tanzania & $\begin{array}{l}\text { Bukoba, Biharamulo, Ngara, } \\
\text { and Kibondo Districts. }\end{array}$ & $\begin{array}{l}\text { Community } \\
\text { based survey }\end{array}$ & Clinical, antigen based & 12(475) & 2.51(1.10-3.92) \\
\hline $\begin{array}{l}\text { Asia } \\
\text { Russel et al., } 1983\end{array}$ & $\begin{array}{l}1974- \\
{[46]}\end{array}$ & India & Imphal, Aizawal \& Bikaner & $\begin{array}{l}\text { Community } \\
\text { based survey }\end{array}$ & $\begin{array}{l}\text { Clinical and } \\
\text { parasitological }\end{array}$ & $9(4,214)$ & $0.21(0.11-0.40)$ \\
\hline
\end{tabular}

https://doi.org/10.1371/journal.pntd.0006324.t001

\section{Discussion}

Podoconiosis is one of the major causes of tropical lymphedema $[2,61]$, but its global prevalence remains elusive. Access to updated evidence on the incidence and prevalence of podoconiosis is essential for guiding and informing global, regional, and national health policies. The

Table 2. Countries reporting existence of podoconiosis.

\begin{tabular}{|c|c|c|}
\hline SN & Country & Evidence included \\
\hline 1 & Brazil & Case report [47] \\
\hline 2 & Sudan & Case report [54] \\
\hline 3 & Angola & Presence report [3] \\
\hline 4 & Chad & Presence report [55] \\
\hline 5 & Colombia & Presence report [3] \\
\hline 6 & Costa Rica & Presence report [3] \\
\hline 7 & Democratic Republic of the Congo & Presence report [3] \\
\hline 8 & Ecuador & Presence report [3] \\
\hline 9 & El Salvador & Presence report [3] \\
\hline 10 & French Guiana & Presence report [3] \\
\hline 11 & Guatemala & Presence report $[3,56]$ \\
\hline 12 & Honduras & Presence report [36] \\
\hline 13 & Indonesia & Presence report [3] \\
\hline 14 & Madagascar & Presence report [3] \\
\hline 15 & Mexico & Presence report $[3,57]$ \\
\hline 16 & Mozambique & Presence report [3] \\
\hline 17 & Niger & Presence report [55] \\
\hline 18 & Nigeria & Presence report [3] \\
\hline 19 & Peru & Presence report [36] \\
\hline 20 & Sri Lanka & Presence report [3] \\
\hline 21 & Suriname & Presence report [3] \\
\hline 22 & Burundi & Survey data [42] \\
\hline 23 & Cameroon & Survey data $[13,22,49,50]$ \\
\hline 24 & Cape Verde & Survey data [28] \\
\hline 25 & Equatorial Guinea & Survey data [3] \\
\hline 26 & Ethiopia & Survey data $[4,20,21,29,33,35,37,38,40,48,58]$ \\
\hline 27 & India & Survey data $[46]$ \\
\hline 28 & Kenya & Survey data $[26,52]$ \\
\hline 29 & Rwanda & Survey data [42] \\
\hline 30 & Sao Tome and Principe & Survey data [45] \\
\hline 31 & Uganda & Survey data $[39,53]$ \\
\hline 32 & United Republic of Tanzania & Survey data [34] \\
\hline
\end{tabular}

https://doi.org/10.1371/journal.pntd.0006324.t002 

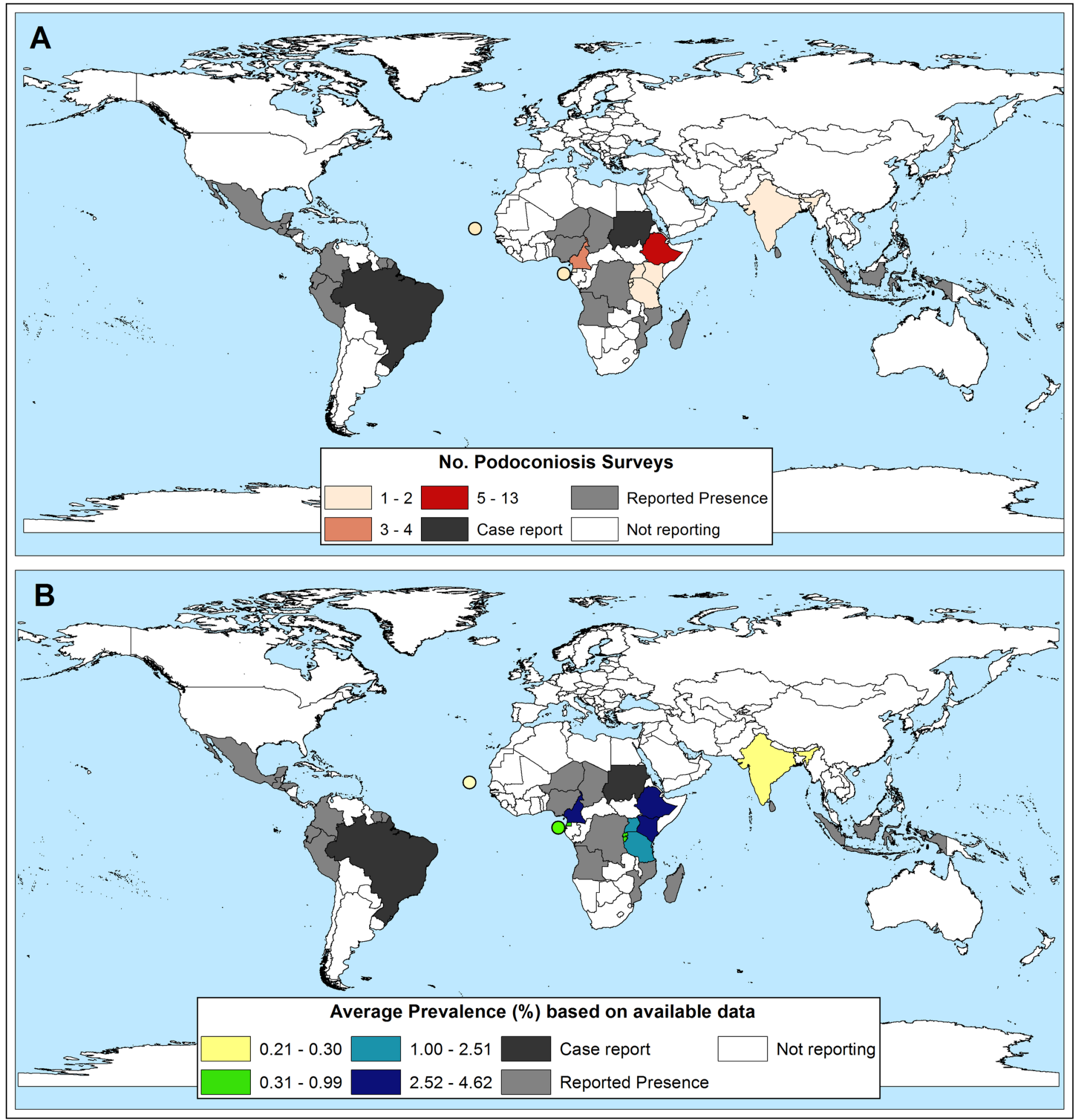

Fig 2. Geographical distribution of A) Surveys included B) Prevalence of podoconiosis. Dots represent various island nations.

https://doi.org/10.1371/journal.pntd.0006324.g002 
systematic review presented here has collated all the currently available literature regarding the prevalence of podoconiosis, and included 27 prevalence studies predominantly from Africa. Although the methods and diagnosis of podoconiosis varied from one study to another, the articles included in this review generally indicated high prevalence of podoconiosis.

Based on the available evidence, 32 countries provided data suggesting the existence of podoconiosis currently or historically. This is based on 11 countries with prevalence data, two countries with case reports and 19 countries with reported presence of the disease but no epidemiological data. The interpretation of these findings is very difficult, particularly for the countries where only presence is reported. Although the rates of poverty and environmental conditions are compatible with the existence of podoconiosis, unless information about the presence of the disease is backed by epidemiological surveys or surveillance data, a national or global response to podoconiosis cannot be initiated. This is particularly evident for countries reporting isolated cases, such as Brazil [47], where only one case was reported in the published literature. It is vital to gather more information on the current status of podoconiosis in countries such as Brazil. Previous experience from endemic countries has showed that underreporting of the disease is very common owing to poor awareness and lack of systematic scrutiny by health workers [62]. Hence, the distribution of podoconiosis might reach beyond the countries listed here, as the necessary environmental and socio-economic conditions exist in other areas.

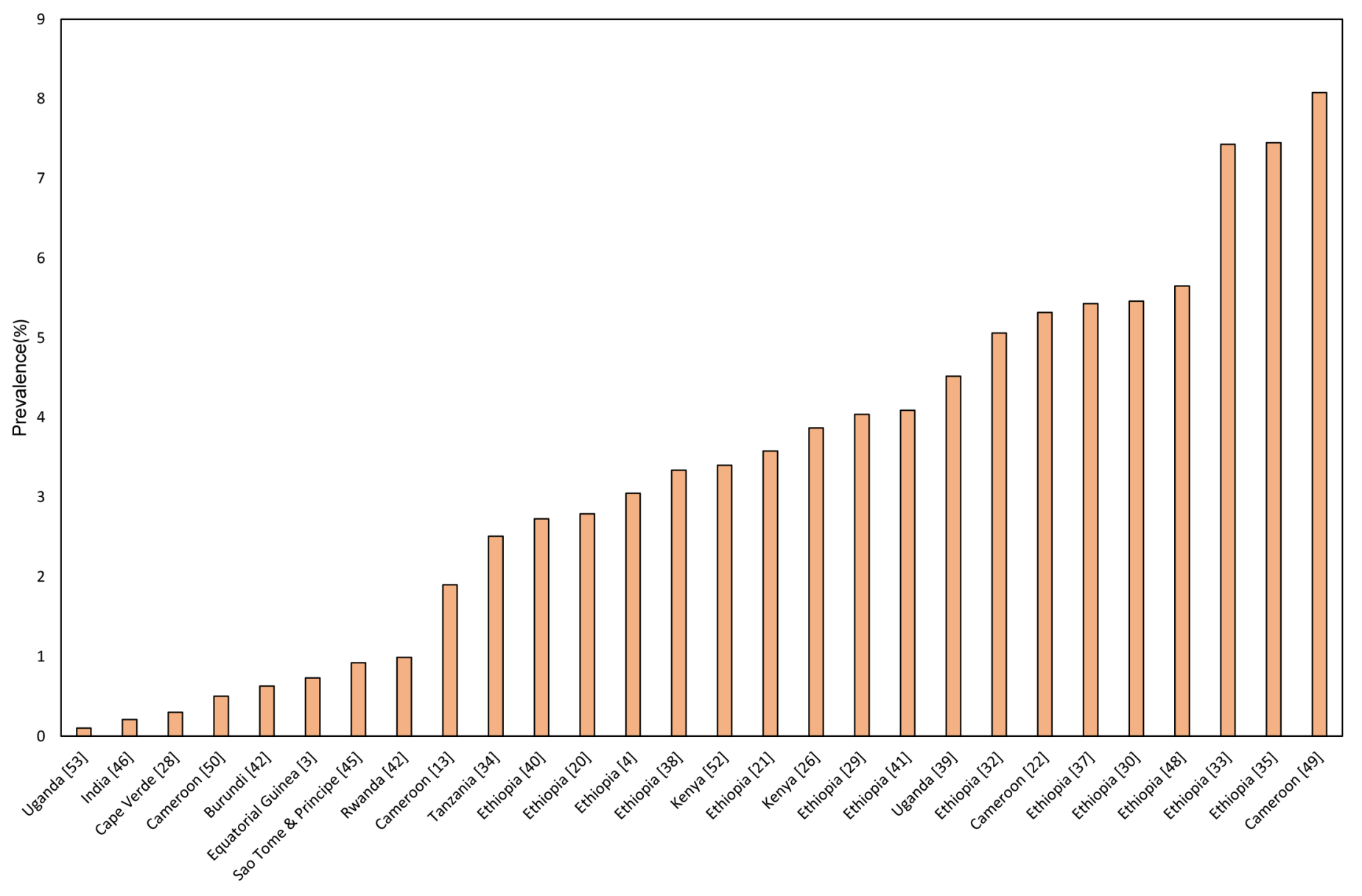

Fig 3. Prevalence of podoconiosis by country.

https://doi.org/10.1371/journal.pntd.0006324.g003 


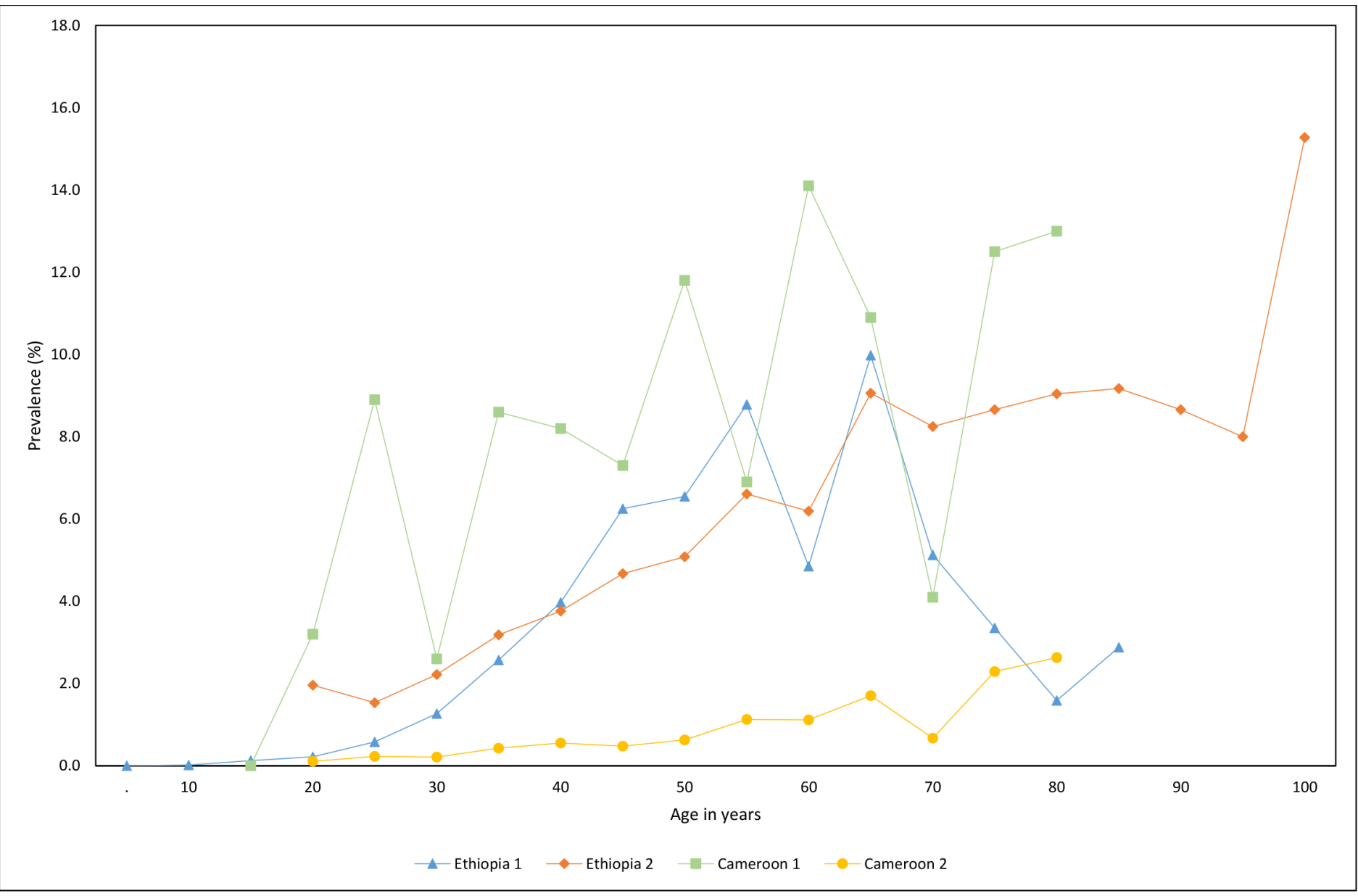

Fig 4. Podoconiosis prevalence by age group in selected studies Ethiopia 1 [4], Ethiopia 2 [29], Cameroon 1 [49] and Cameroon 2 [50].

https://doi.org/10.1371/journal.pntd.0006324.g004

While the purpose of the current review is to increase robust surveillance in the listed countries, we would like to emphasize the list here is only guided by the available literature.

Most of the highly-affected countries are in African Region. In this region, we identified prevalence data from 10 countries (Burundi, Cameroon, Cape Verde, Equatorial Guinea, Ethiopia, Kenya, Rwanda, Sao Tome \& Principe, Uganda and Tanzania). India is the only country with prevalence data outside of the African Region, and these data are more than three decades old. The prevalence of podoconiosis is particularly high in Cameroon [49], Ethiopia [32, 33, 35] and Uganda [39]. The high prevalence of the disease in these countries could be due to low levels of footwear use and access to water, along with environmental suitability for the occurrence of the disease, namely highland rural areas, with high precipitation and soil typically rich in silt and clay particles [29]. Previous studies have indicated that $24 \%$ of the landmass in Ethiopia (where $44 \%$ of the population lives) is suitable for the occurrence of podoconiosis [59]. Similarly, in Cameroon the disease is widespread and cases were identified in every region of the country [50].

Our study has some limitations. We did a comprehensive systematic review of the published literature on the prevalence of podoconiosis, but we chose not to do a meta-analysis because of variability between studies. The major issue here is the diagnosis of podoconiosis. Until recently there was no standardized case definition for podoconiosis [63, 64]. Earlier 
studies used clinical diagnosis of podoconiosis, without clear indication of how other potential causes of lymphedema were excluded. More recent studies have used a combination of clinical, parasitological and molecular techniques to exclude other potential causes of lymphedema [10, 50]. Some recent studies did not outline how the diagnosis of podoconiosis was established. In an attempt to standardize podoconiosis surveys, we have provided guidance based on consensus and evidence-based diagnosis of podoconiosis [65]. The other limitation of the collated studies is that surveys tended to be conducted in areas where podoconiosis was suspected to be an important problem, which may lead to overestimation of the prevalence. Nonetheless there are exceptions where nationwide surveys were conducted, including in Burundi [42], Cameroon [50], Ethiopia [29] and Rwanda [42]. Most of the data included in this review are from the African Region as data are scarce for other regions of the world. Countries in which podoconiosis is less prevalent may have not reported the disease, leading to publication bias. Finally the quality of the studies included in the review is generally poor. This calls for standardized diagnostic and survey methods to be used in future work as we progress towards developing the global atlas of podoconiosis[65].

This systematic review provides a comprehensive global overview of the prevalence of podoconiosis. We found podoconiosis to be a common public health problem affecting underprivileged areas of the tropics with particularly high prevalence in the African Region. Despite the methodological limitations of most of the studies conducted, the evidence cumulatively indicates that podoconiosis remains an important and unrecognized public health problem in this region. As noted by Hotez recently, podoconiosis is a clear example of a disease of enormous importance which has been neglected by the global community [66]. To address this neglect, control and prevention interventions must be expanded in countries recognized to be endemic. Standardized population based surveys will be vital in clarifying the global distribution of podoconiosis and further accelerating the elimination of this preventable and treatable disease.

\section{Supporting information}

S1 Checklist. PRISMA checklist.

(DOC)

S1 Text. Supplementary file: Search strategy and quality of included studies. (DOCX)

\section{Author Contributions}

Conceptualization: Kebede Deribe, Melanie J. Newport, Gail Davey.

Data curation: Kebede Deribe, Jorge Cano, Mei L. Trueba, Gail Davey.

Formal analysis: Kebede Deribe, Jorge Cano, Gail Davey.

Funding acquisition: Melanie J. Newport, Gail Davey.

Investigation: Kebede Deribe.

Methodology: Kebede Deribe, Gail Davey.

Software: Kebede Deribe, Jorge Cano.

Supervision: Gail Davey.

Validation: Kebede Deribe.

Visualization: Kebede Deribe, Jorge Cano. 
Writing - original draft: Kebede Deribe.

Writing - review \& editing: Jorge Cano, Mei L. Trueba, Melanie J. Newport, Gail Davey.

\section{References}

1. Davey G, Tekola F, Newport MJ. Podoconiosis: non-infectious geochemical elephantiasis. Trans R Soc Trop Med Hyg. 2007 101(12):1175-80. https://doi.org/10.1016/j.trstmh.2007.08.013 PMID: 17976670

2. Deribe K, Tekola-Ayele F, Davey G. Podoconiosis: Endemic non-filarial elephantiasis In: Gyapong J, Boatin B, editors. Neglected Tropical Diseases-Sub-Saharan Africa 1st ed 2016 Edition. 1. Switzerland: Springer International Publishing; 2016. p. 231-49.

3. Price E. Podoconiosis:Non-filarial Elephantiasis. Oxford Medical Publications, Oxford, UK. 1990.

4. Bekele K, Samuel A, Ambebir T, Deribe K, Davey G. Burden of Podoconiosis in Wayu Tuka Woreda, East Wollega Zone, Western Ethiopia. BMJ Open. 2016; 6(9):e012308. https://doi.org/10.1136/ bmjopen-2016-012308 PMID: 27670520

5. Davey G, GebreHanna E, Adeyemo A, Rotimi C, Newport M, Desta K. Podoconiosis: a tropical model for gene-environment interactions?. Trans R Soc Trop Med Hyg 2007; 101(1):91-6. https://doi.org/10. 1016/j.trstmh.2006.05.002 PMID: 16884751

6. Tekola Ayele F, Adeyemo A, Finan C, Hailu E, Sinnott P, Burlinson ND, et al. HLA class II locus and susceptibility to podoconiosis. N Engl J Med 2012; 366(13):1200-8. https://doi.org/10.1056/ NEJMoa1108448 PMID: 22455414

7. WHO. Neglected tropical diseases: Podoconiosis: endemic non-filarial elephantiasis. Accessed on 17 January; Available at [http://www.who.int/lymphatic_filariasis/epidemiology/podoconiosis/en/]. 2018.

8. Negussie H, Kassahun MM, Fegan G, Njuguna P, Enquselassie F, McKay A, et al. Podoconiosis treatment in northern Ethiopia (GoLBet): study protocol for a randomised controlled trial. Trials. 2015; 16 (307).

9. Davey G, Bockarie M, Wanji S AD, Fuller C, Fox L, Mycoskie M, et al. Launch of the International Podoconiosis Initiative. Lancet. 2012; 379 (9820):1004. https://doi.org/10.1016/S0140-6736(12)60427-9 PMID: 22423883

10. Sime H, Deribe K, Assefa A, Newport MJ, Enquselassie F, Gebretsadik A, et al. Integrated mapping of lymphatic filariasis and podoconiosis: lessons learnt from Ethiopia. Parasit Vectors. 2014; 7(1):397.

11. Desta K, Ashine M, Davey G. Predictive value of clinical assessment of patients with podoconiosis in an endemic community setting. Trans R Soc Trop Med Hyg. 2007; 101(6):621-3. https://doi.org/10.1016/j. trstmh.2006.12.002 PMID: 17316723

12. Deribe K, Kebede B, Tamiru M, Mengistu B, Kebede F, Martindale S, et al. Integrated morbidity management for lymphatic filariasis and podoconiosis, Ethiopia. Bull World Health Organ. 2017; 95(9):6526. https://doi.org/10.2471/BLT.16.189399 PMID: 28867846

13. Wanji S, Kengne-Ouafo JA, Datchoua-Poutcheu FR, Njouendou AJ, Tayong DB, Sofeu-Feugaing DD, et al. Detecting and staging podoconiosis cases in North West Cameroon: positive predictive value of clinical screening of patients by community health workers and researchers. BMC Public Health. 2016; 16:997. https://doi.org/10.1186/s12889-016-3669-6 PMID: 27650390

14. Morrone A, Padovese V, Dassoni F, Pajno MC, Marrone R, Franco G, et al. Podoconiosis: an experience from Tigray, Northern Ethiopia. J Am Acad Dermatol. 2011; 65(1):214-5. https://doi.org/10.1016/j. jaad.2010.08.018 PMID: 21679822

15. Smith JL, Haddad D, Polack S, Harding-Esch EM, Hooper PJ, Mabey DC, et al. Mapping the global distribution of trachoma: why an updated atlas is needed. PLoS Negl Trop Dis. 2011; 5(6):e973. https:// doi.org/10.1371/journal.pntd.0000973 PMID: 21738814

16. Brooker, S PJ H, Bundy DA. The global atlas of helminth infection: mapping the way forward in neglected tropical disease control. PLoS Negl Trop Dis. 2010; 4(7):e779. https://doi.org/10.1371/ journal.pntd.0000779 PMID: 20668545

17. Liberati A, Altman DG, Tetzlaff J, et al. The PRISMA statement for reporting systematic reviews and meta-analyses of studies that evaluate healthcare interventions: explanation and elaboration. BMJ 2009; 339:b2700. https://doi.org/10.1136/bmj.b2700 PMID: 19622552

18. Tomczyk S, Deribe D, Brooker SJ, Clark H, Rafique K, Knopp S, et al. Association between Footwear Use and Neglected Tropical Diseases: A Systematic Review and Meta-Analysis. PLoS Negl Trop Dis. 2014; 8(11):e3285. https://doi.org/10.1371/journal.pntd.0003285 PMID: 25393620

19. GADM. GADM database of Global Administrative Areas, version 2.8. Available at www.gadm.org. Accessed August 15,2016. 
20. Alemu G, Tekola Ayele F, Daniel T, Ahrens C, Davey G. Burden of podoconiosis in poor rural communities in Gulliso woreda, West Ethiopia. PLoS Negl Trop Dis. 2011; 5(6):e1184. https://doi.org/10.1371/ journal.pntd.0001184 PMID: 21666795

21. Birrie H, Balcha F, Jemaneh L. Elephantiasis in Pawe settlement area: podoconiosis or Bancroftian filariasis?. Ethiopian Medical Journal. 1997; 35(4):245-50. PMID: 10214438

22. Cho-Ngwa F, Amambua AN, Ambele MA, Titanji VPK. Evidence for the exacerbation of lymphedema of geochemical origin, podoconiosis, by onchocerciasis. Journal of Infection and Public Health 2009; 2 (4):198-203. https://doi.org/10.1016/j.jiph.2009.09.006 PMID: 20701883

23. Clark M. Lymphostatic Verrucosis in the Fort Hall District of Kenya. Trans R Soc Trop Med Hyg. 1948; 42(3):287-90.

24. Cohen LB. Idiopathic lymphoedema of Ethiopia and Kenya. East Afr Med J. 1960; 37:53-74. PMID: 13694397

25. Corachan M, Tura JM, Campo E, Soley M, Traveria A. Podoconiosis in Equatorial Guinea. Report of two cases from different geological environments. Trop Geogr Med 1988; 40(4):359-64. PMID: 3227560

26. Crivelli PE. Non-filarial elephantiasis in Nyambene range: a geochemical disease. East Afr Med J. 1986; 63(3):191-4. PMID: 3743481

27. de Lalla $F$, Zanoni $P$, Lunetta $Q$, Moltrasio $G$. Endemic non-filarial elephantiasis in Iringa District, Tanzania: a study of 30 patients. Trans R Soc Trop Med Hyg 1988; 82 (6):895-7. PMID: 3256993

28. De Meira MTV, Somoes TS, Nogueira JFP. On the existence of mossy foot on the island of St Nicolau (Cape Verde). Ann Inst Med Trop (Lisbon) 1947; 4:269-79.

29. Deribe K, Brooker SJ, Pullan RL, Sime H, Gebretsadik A, Assefa A, et al. Epidemiology and individual, household and geographical risk factors of podoconiosis in Ethiopia: results from the first nationwide mapping. Am J Trop Med Hyg. 2015; 92(1):148-58. https://doi.org/10.4269/ajtmh.14-0446 PMID: 25404069

30. Desta K, Ashine M, Davey G. Prevalence of podoconiosis (endemic non-filarial elephantiasis) in Wolaitta, Southern Ethiopia Tropical Doctor. 2003; 33(4):217-20. https://doi.org/10.1177/ 004947550303300410 PMID: 14620426

31. Dwek P, Kong LY, Wafer M, Cherniak W, Pace R, Malhamé I, et al. Case Report and Literature Review: Podoconiosis in Southwestern Uganda. International Journal of Topical Disease \& Health. 2015; 9 (3):1-7.

32. Frommel D, Ayranci B, Pfeifer HR, Sanchez A, Frommel A, Mengistu G. Podoconiosis in the Ethiopian Rift Valley. Role of beryllium and zirconium. Trop Geogr Med 1993; 45(4):165-7. PMID: 8236466

33. Geshere Oli G, Tekola Ayele F, Petros B. Parasitological, serological, and clinical evidence for high prevalence of podoconiosis (non-filarial elephantiasis) in Midakegn district, central Ethiopia. Trop Med Int Health. 2012; 17(6):722-6. https://doi.org/10.1111/j.1365-3156.2012.02978.x PMID: 22487446

34. Jordan P, Hope Trant M, Laurie W. Non-Bancroftian Elephantiasis in Tanganyika. British Medical Journal 1956; 1(4960):209-10. PMID: 13276677

35. Kloos H, Kello AB, Addus A. Podoconiosis (endemic non-filarial elephantiasis) in two resettlement schemes in western Ethiopia. Tropical Doctor. 1992; 22(3):109-12. https://doi.org/10.1177/ 004947559202200306 PMID: 1641880

36. Lowenthal LJA. On the probable inclusion of several diseases in the title "mossy" foot. Ann Trop Med Parasitol 1934; 28:47-57.

37. Mengistu G, Humber D, Ersumo M, Mamo T. High prevalence of elephantiasis and cutaneous leishmaniasis in Ocholo, south-west Ethiopia. Ethiop Med J. 1987; 25(4):203-7. PMID: 3665892

38. Molla YB, Tomczyk S, Amberbir T, Tamiru A, Davey G. Podoconiosis in East and West Gojam zones, Northern Ethiopia. PLoS Negl Trop Dis. 2012; 6(7):e1744. https://doi.org/10.1371/journal.pntd.0001744 PMID: 22816005

39. Onapa AW, Simonsen PE, Pedersen EM. Non-filarial elephantiasis in the Mt. Elgon area (Kapchorwa District)of Uganda. Acta Trop. 2001; 78(2):171-6. PMID: 11230827

40. Oomen AP. Studies on elephantiasis of the legs in Ethiopia. Trop Geogr Med. 1969; 1969 (21):3.

41. Price EW. Endemic elephantiasis of the lower legs in Ethiopia an epidemiological survey. Ethiop Med J. 1974; 12(2):77-90. PMID: 4459134

42. Price EW. Endemic elephantiasis of the lower legs in Rwanda and Burundi. Trop Geogr Med. 1976; 28 (4):283-90. PMID: 1014068

43. Price EW, Bailey D. Environmental factors in the etiology of endemic elephantiasis of the lower legs in tropical Africa. Trop Geogr Med 1984; 36(1):1-5. PMID: 6328708 
44. Price EW, Henderson WJ. Endemic elephantiasis of the lower legs in the United Cameroon Republic. Trop Geogr Med 1981; 33(1):23-9. PMID: 7245337

45. Ruiz L, Campo E, Corachan M. Elephantiasis in Sao Tome and Principe. Acta Trop. 1994; 57(1):29-34. PMID: 7942352

46. Russel S, Krishna Rao C, Rao CK. Prevalence of nonfilarial elephantiasis in selected towns in India. The Journal of communicable diseases. 1983; 15(3):216-8. PMID: 6672090.

47. Tada MS, Marsden PD. Probable podoconiosis in Brasilia. Rev Soc Bras Med Trop. 1993; 26(4):255. PMID: 8159829

48. Tekola Ayele F, Alemu G, Davey G, Ahrens C. Community-based survey of podoconiosis in Bedele Zuria woreda, southwest Ethiopia. Int Health. 2013; 5(2):119-25. https://doi.org/10.1093/inthealth/ int003 PMID: 24030111

49. Wanji S, Tendongfor N, Esum M, Che JN, Mand S, Tanga Mbi C, et al. Elephantiasis of non-filarial origin (podoconiosis) in the highlands of north-western Cameroon. Ann Trop Med Parasitol. 2008; 102 (6):529-40. https://doi.org/10.1179/136485908X311849 PMID: 18782492

50. Deribe K, Andrew AB, Cano J, Jelil A, Fru-Cho J, Raphael A, et al. Mapping the geographical distribution of podoconiosis in Cameroon using parasitological, serological, and clinical evidence to exclude other causes of lymphedema. PLoS Negl Trop Dis. 2017 12(1):e0006126.

51. Price EW. The relationship between endemic elephantiasis of the lower legs and the local soils and climate: A study in Wollamo District, Southern Ethiopia. Trop Geogr Med 1974; 26(3):225-30. PMID: 4439458

52. Muli J, Gachohi J, Kagai J. Soil iron and aluminium concentrations and feet hygiene as possible predictors of Podoconiosis occurrence in Kenya. PLoS Negl Trop Dis. 2017; 11(8):e0005864. https://doi.org/ 10.1371/journal.pntd.0005864 PMID: 28832604

53. Kihembo C, Masiira B, Lali WZ, Matwale GK, Matovu JKB, Kaharuza F, et al. Risk Factors for Podoconiosis: Kamwenge District, Western Uganda, September 2015. Am J Trop Med Hyg. 2017; 96(6):14906. https://doi.org/10.4269/ajtmh.16-0932 PMID: 28719274

54. Price EW. Non-filarial elephantiasis of the lower legs in Ethiopia. A simple method for rapid survey by school enquiry. Trop Geogr Med. 1973; 25(1):23-7. PMID: 4693995

55. Nenoff $P$, Simon JC, Muylowa GK, Davey G. Podoconiosis-non-filarial geochemical elephantiasis-a neglected tropical disease?. J Dtsch Dermatol Ges 2009; 8(1):7-14.

56. Robles R. Pseudo-Leprosy or Punudos, an Unclassed Disease of Guatemala. Bull Acad Med. 1927; 97 (23):776-80.

57. Mazzotti L. Pseudo-Leprosy of Robles in Mexico. Medicina 1941;21(383):103-7.

58. Desta K, Ashine M, Davey G. Prevalence of podoconiosis (endemic non-filarial elephantiasis) in Wolaitta, Southern Ethiopia. Tropical Doctor. 2003; 33(4):217-20. https://doi.org/10.1177/ 004947550303300410 PMID: 14620426

59. Deribe K, Cano J, Newport MJ, Golding N, Pullan RL, Sime H, et al. Mapping and modelling the geographical distribution and environmental limits of podoconiosis in Ethiopia. PLoS Negl Trop Dis 2015; 9 (7):e0003946. https://doi.org/10.1371/journal.pntd.0003946 PMID: 26222887

60. Deribe K, Cano J, Giorgi E, Pigott DM, Golding N, Pullan RL, et al. Estimating the number of cases of podoconiosis in Ethiopia using geostatistical methods. Wellcome Open Res 2017; 2(78).

61. Molyneux DH. Tropical lymphedemas—control and prevention. N Engl J Med 2012; 366(13):1169-71 https://doi.org/10.1056/NEJMp1202011 PMID: 22455411

62. Yakob B, Deribe K, Davey G. Health professionals' attitudes and misconceptions regarding podoconiosis: potential impact on integration of care in southern Ethiopia. Trans R Soc Trop Med Hyg. 2010; 104 (1):42-7. https://doi.org/10.1016/j.trstmh.2009.07.021 PMID: 19717176

63. Deribe K, Wanji S, Shafi O, Muheki E, Umulisa I, Davey G. Measuring Elimination of Podoconiosis, Endemicity Classifications, Case Definition and Targets: An International Delphi Exercise. Int Health 2015; 7(5):306-16. https://doi.org/10.1093/inthealth/ihv043 PMID: 26185194

64. Deribe K, Wanji S, Shafi O, Tukahebwa EM, Umulisa I, Molyneuxf DH, et al. The feasibility of eliminating podoconiosis. Bull World Health Organ 2015; 93(10):712-8. https://doi.org/10.2471/BLT.14.150276 PMID: 26600613

65. Deribe K, Cano J, Newport MJ, Pullan RL, Noor AM, Enquselassie F, et al. The global atlas of podoconiosis. Lancet Glob Health. 2017; 5(5):e477-e9. https://doi.org/10.1016/S2214-109X(17)30140-7 PMID: 28395836

66. Hotez JP. Ten failings in global neglected tropical diseases control. PLoS Negl Trop Dis 2017; 11(12): e0005896. https://doi.org/10.1371/journal.pntd.0005896 PMID: 29267282 